\title{
THE INVESTIGATION OF THE ROLE OF COHESION AND REUNIFICATION OF ACHAEMENIAN WITH LOCAL NOBLES IN THE ART OF ACHAEMENIAN IN CENTRAL ASIA
}

\author{
Sharareh Soheili \\ Department of History, Shabestar branch, Islamic Azad University, Shabestar, Iran \\ shararehsoheily@gmail.com
}

\begin{abstract}
Although the achaemenians were composed of many various lands and ethnics along with different cultural affairs in their own vast and sophisticated territories but they could display the most outstanding art with specified framework and features for showing the power and glory of the king that this could distributed even in the neighborhood states such as the central Asia at that era. Undoubtedly, this kind of success requires some sophisticated thoughts and approaches that the main reason for this outstanding approach is subjected to the cohesion and reunification with local nobles. The achaemenians could obtain the cooperation of the local nobles in order to transfer, support and publish their ideological purposes and cultures in this pavement. This kind of political policies from the achaemenian kings has led to the appearance of the achaemenian royal art going towards the imitation style of the achaemenian royal art or the extracted art from the achaemenian royal art in the central Asia states.
\end{abstract}

Keywords: Local Nobles, Achaemenians, Central Asia, Artistic Style of royal achaemenian, Imitative Style of achaemenian royal art, Extracted style from the achaemenian royal art

\section{INTRODUCTION}

The central Asia area has been defined by many various ways but generally the main aim of the central Asia is subjected to those lands having the small and big rivers coming and rooting from Pamir and Hendokosh as well as Tian Shan Mounts (Frankfort, 1988), this land is one of those territories where it has been under the power of the achaemenian sovereignty; this land has been always under the power of emperor during its political history. The annexed history of the central Asia by the achaemenian emperor is not accurately specified because the classical writers have not shown their own interest in this land until the Alexander military expedition to this territory; these writers have little written all about the achameneians and they only pointed to the final battle of the Great Koroush with Masazhets in summary. Today's historians have pointed to the accurate date of Koroush military expedition towards central Asia and conquer between the years 540-546BC (Bryan, 1997) because Dariush mentions all the states in Bistoon manuscript and it is specified that before Koroush these areas have been subjected to the emperor (Vogelsang, 1992). Among of the central Asia cities including the states of Kharazm, Part, Bacteria, Sagd, Skates, the Bacteria, Sagd and Kharazm are the most important cities of the achaemenians at that era (Kertice \& Talice, 2013). The achaemenians had some programs in order to conduct and make their own leadership over these related states because this made them how to manage and support the emperor by this way (Dusinberre, 2002); these are the most sophisticated programs including the cohesion and reunification with nobles and local governors (Brosius, 2010).

\section{The cohesion and reunification with local nobles}

There were established noble people in the emperor of the achaemenian that they had a mutual relationship with the achaemenian kings so that they used to cooperate with the political and cultural 
ideology of achamenian kings. In turn, the king used to give some gifts to these nobles for their cooperation in this pavement (Tuplin, 2007, 211-215). Generally, there have been established two important political organizations in the emperor of the achaemenians attractively: the control of state and control organizations; that is, the autonomous of all achamenian emperor cities is completely conducted by these nobles in order to transfer the emperor ideology because this will increase the relative power and security at that time (Xin, 2005). In other words, the local nobles are acting like interventions between the achaemenian legislations and the local population constructing all local infrastructures in order to make both sides to benefit from these issues (Carstens, 2006). Since the beginning of the achaemenian kingdom or monarchy era, due to the lack of kingdom vastness and the lack of Persian military force, Koroush decided to achieve the politics as a great remedial for conducting the country's political affairs at that time. In his era, all officials have been established or removed from their own positions. Hence, it is completely apparent that the forced loyalty is the main determinant condition of this era. For the reason, all nobles are always concerning about their own points trying not achieving any mistakes in this pavement because of getting removed from their position (Rajabi, 2008). This method continued since Daruish I but in Khashayarsha era due to the development of the lands and territories in the emperor and the highest struggle to stabilize the power of the sovereignty and conquer of the achaemenians, the priority of the local people over the Persian satraps and their own forces such as the era of Koroush and achaemenian kings made them to move the nobles from the sensitive states giving the most fertilized lands to these nobles asking them to meet all achamenians requirements. Since Ardeshir I the money policy is appeared, the achaemenian kings used to give some gifts to the local nobles as the financial gifts considering these nobles as the most sophisticated people at that time; even the achaemenian kings used to give some important tasks of the country to these local nobles. These people also were able to get benefited of some gifts and special labels or titles from the king. Of course, these nobles had to cooperate with the kings in order to get their own title in this pavement. Achaemeninas also used to permit these local nobles to occupy an area by the name of themselves and this is the same policy that has been conducted in relation to Yahoudieh, Cyprus and Karia (Mirzaee, 2010); this has been also achieved in relation to Phinighieh and Ayounia regarding to achieve the military and financial tasks (Wright, 2012). In addition to this, the marriage between the Persian members and the local nobles assisted on the reunification of these nobles with the central emperor at that time potentially (Brosius, 2014). Hence the conducted policies to reunite the achaemenian kings with local nobles could apparently bring the power for the kings and this has also made them to make remedy with the Iranian sovereignty trying to make some new functional and ideological frameworks together (Wiesehofer, 2009). Also, the local nobles were responsible for their tasks to imitate all arts and various traits of the achaemenian kings so that these have to follow and obey all kings' traits in their own arts and even their clothes (Mirzaee, 2010). Therefore, by these Persian-making methods, governing the achaemenian ideology has been built and the praise of royal people and others towards the imitation of the achameneian works from the local noble could also assisted on the solidarity of the achaemenian emperor at that era (Wright, 2012).

\section{Obtained artistic styles from the reunification of the local nobles}

According to the mentioned political programs to publish and support the emperor ideology, the achaemenian art regarding to the following states can be divided in different styles as following:

1- Achaemenian royal art style

2- Imitative style of the achaemenian royal art

3- Extracted style of the achaemenian royal art

Achaemenian royal art style:

This art is related to the kingdom royalty; the produced art works by this style in the emperor states have been gifted by the achameneian kings and these have been also claimed as the symbols from the priority in the related states; thus, the existence of these artistic works in the emperor states represent the acceptance and support of the achameneian king through people and local nobles (Xin, 2005).

Submit Date: 10.07.2016, Acceptance Date: 22.09.2016, DOI NO: 10.7456/10604100/009

Copyright (C) The Turkish Online Journal of Design, Art and Communication 


\section{Imitative style of the achameneian royal art}

The artistic works of this group are directly subjected to nobles and local nobles; in other words, the productions are the creative process of all local nobles and local artists in this area. The imitative style is a style that it has been generalized in the states of the achaemenian emperor and the local nobles showed themselves through this style towards their own alleys and neighbors (Ibid, 264). These local nobles were the main customers of the achaemenian art works using these as the main symbol for transferring the Persian kingdom in this regard.

\section{The extracted style of the achaemenian royal art}

The artistic works of this group are combinations of the achaemenian royal art, state art and Greek art together. The Persian-Greek style is also established in this artistic group. The Greek effect of these works due to the neighborhood of Greek cities in the seashore of Mediterranean Sea in one hand and on the other hand the immigrants of the Greek along the same sea can represented the related effects of these works together (Rehm, 2010, 177). Generally, it can be stated that the extracted artistic works from the achaemenian royal art is a kind of reflection of formation changes deviating from the achaemenian royal art in the local or state art style (Xin, 2005, 229). Hence, due to the mentioned statements, along with little thinking in the architectural art, the metal-working and stamp-working of the achaemenian can be established in these styles in the central Asia; so it can be confronted with the consequence of the relationship or the local nobles reunification and the achaemenian emperor center.

\section{Achaemenian architecture in central Asia}

Since the columned halls of the central Asia is only appeared after the beginning of the achaemenian sovereignty in this area (Firouzmandi \& Bahadori, 2012), it can be claimed that the architecture of the luxury buildings in the central Asia shows the relationship of achaemenians with the tribes of the central Asia (figure 1) that among this due to the observations, the penetration of the achaemenians is strongly appeared in Kharazm and this is only rooted and extracted from the achaemenian architecture in this case (Xin, 2005).

\section{Achaemenian metal-working in central Asia}

Generally, in relation to the metal objects of the central Asia, it can be stated that the achaemenian royal style and the imitation style of the achaemenian royal style can be seen in the metal works. The metal objects in the central Asia states have got the engraved motifs of the royalty palaces and other stamp symbols and these are also very similar to the burial objects of the emperor (burial from Shoush) regarding to the achaemenian royal style group (Aruz et al., 2000). These objects are mainly appeared as the kingdom gifts that they have been give to the local nobles as the memorial symbols. Hence, the existence of these dishes in the central Asia is the main acceptance or the support acceptance of the Persian kings through the central Asia tribes. All these metal objects show the achaemenian royal art style due to the struggles for making relationship with the social models in this pavement; also, these can be established in the imitative style group from the achaemenian emperor royal style (Xin, 2005). In relation to the most important metal objects regarding to the central Asia, it can be stated that the treasure objects of Jeihoun in Bacteria State are the most sophisticated cases in this regard. generally, Jeihoun treasure objects have been built by industrialists familiar with achaemenian royal art style in Amoudarya area and another part in Eastern area (according to the engraved motifs in Apadana) that these are wholly used to be sent to the king and the king distribute these between the agencies; these objects represent that they have been established in a very restricted center with the governor class being centralized among the local 
nobles having a close relationship with achaemenian king. Therefore, the metal objects of this era represent the achaemenian royal style and the relationship of local nobles with the central emperor (Ibid). From these works, it can be pointed to the golden plaques and animal sculptures with the achaemenian elements and contexts (figure 2) (Ibid). In addition to this, Balkhi treasure or the Mirzagheh II are really similar to the Jeihoun treasure having a combination of the Persian, Greek and Balkhi objects together (Frankfort, 2013); these all objects are subjected to the extracted style of achaemenian royal art.

\section{Achaemenian stamps in central Asia}

Generally, by investigating the stamps of the central Asia states, it can be concluded that the displayed scenes of the stamps have been equally deviated and rooted from Takht-e-Jamshid having the royal style and or they are a combination of the Greek-Persian-Local art together that in this case the subjects and contexts of these stamps are sometimes Persian and the formation of the stamp is local and they are also sometimes a combination of the Persian technically. Hence, the stamps of the related era in central Asia have been produced by the imitation of the achaemenian formal workshops and or they have been produced by the extraction of the sculpturing and details of the early Persian samples regarding to the local artistic; based on this, these can be also established in the group of achaemenian royal art styles (Xin, 2005). For example, the stamp of Afrasiab area in central Asia showing a man with beard and sitting can be subjected to the local imitation from the achaemenian royal art style so that the jagged crown and long skirt and ilami shirt are the main sophisticated features of the related art showing the achaemenian contexts in this regard (figure 3) (Ibid). The stamp belonging to Jeihoun treasure in Bacteria shows a woman picture giving a gift to sitting person that it comes from the Greek-Persian artistic style. The type of displayed scene on the related stamp is subjected to the achaemenian scenes and on the other hand the complete formation of the woman body is related to the Greek style (Ibid). therefore, the related stamp is established in the extracted royal art of achaemenian group (figure 4). The stamp of Ay Khanoum Temple showing an animal walking is also established in the Persian-Greek style. The way of showing the animal on the stamp is subjected to the naturalism style of Greek having the achaemenian type of art (figure 5). There is another stamp having a Persian soldier having a spear on his hands conquering against his enemy (Sakaee \& Iranian) can be also established into the Jeihoun treasure art style; this has been also shown along with a winged sculpture on top of his head indicating the context of the achaemenian art style in this pavement (Allen, 2009). In the stamps of the achaemenian emperor, the military quarrels have been pictured between the different territories that finally conquer of the Persians has been proofed for achaemenians and their alleys particularly in Mad and Ilam in this emperor. The most important note should be mentioned is that in most stamps in the central emperor, the failed tribes were mainly from the tribes of central Asia such as Sagdian, Kharazmian, Sakkaha and Bacteria. For example, three stamps of Takht-e-Jamshid show the quarrels of Khashayarsh brother's turmoil as the governor of Bacteria and as a result this would be toppled down the king. From the picture of these stamps, it is specified that Sagdian are those tribes that they have fought against Persians more than other states. Hence those ones having continuous relations with the emperor center, these stamps are the main reflective from the achaemenian political viewpoint and these have taken this common style in the sculpture and based on this the motifs on the stamps have been mainly subjected to the extraction of the royal achamenian art like Jeihoun treasure along with military challenges context (Xin, 2005). In a stamp from Kharazm in the area of Kiozlighir, the picture of the stamp shows a man moving and being followed by an accompanying person so that there is a picture of enemy being failed between these two persons and there are some animals jumping in the air. Hence, this stamp from the battle fields is very common in the achaemenian art but the square formation of this stamp is rooted from the local production art. For the reason, the mentioned stamp is established in the extracted style group from the achaemenian royal art style (Ibid, 209). 


\section{Conclusion}

Along with evaluating the architectural art, metal-working, stamp-working in the states of the central Asia can be seen in the achaemenian era and or they are a combination of the achaemenian royal art coming from the allocated policies of the achaemenian kings in this land and this has been established as one of the most essential policies for the local emperor with the emperor. In other words, the local nobles or the local lords play key role in transferring all ideas and cultural points in the emperor cultures for keeping their own position in the pavement of the kingdom. The royal art style is seen in the framework of metal-working in the central Asia states as the king gift giving to all local nobles. The imitative style of the royal art is also established in the cooperation of the nobles with achaemenian kings and most of these works have been appeared in central Asia artistic works. The extracted style or the combinative style also include the Persian, local and Greek elements that these have been also seen in the central Asia area. Hence, a kind of Persian-making culture of the states in this area has been achieved by the local nobles and lords that these are also observed in the related art as well.

Figures:

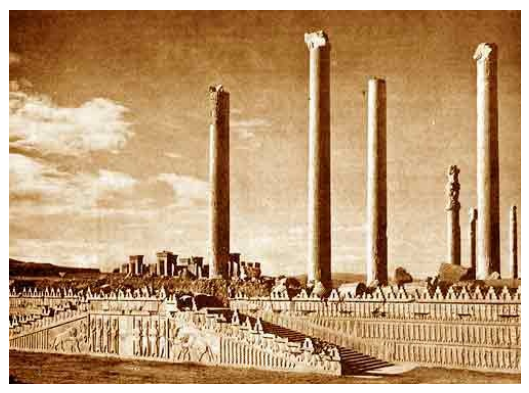

Rehabilitated pictures of Kolalighir Palace (Firouzmandi \& Bahadori, 2011).

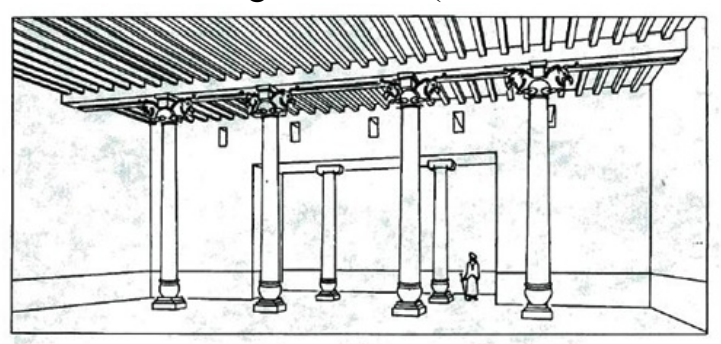

General Façade of Apadana Palace in Takht-e-Jamshid (Veisi, 2009).

Figure 1. The comparison of the columned hall of Kharazm with columned hall of Tkht-e-Jamshid.

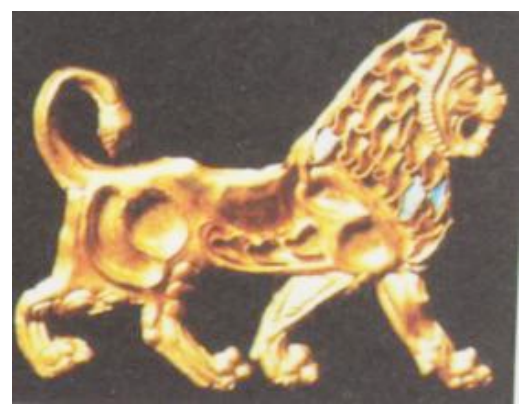

Golden hanger of achaemenian (Dadvar \& Barazandeh Hosseini, 2013). 


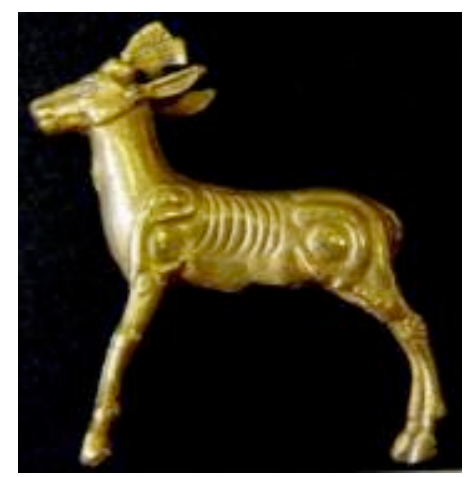

Sample of metal sculpture in central Asia (Xin, 2005).

Figure 2. The comparison of the achaemenian animal sculpture with the sample of central Asia regarding to the applied elements in designing the muscles.

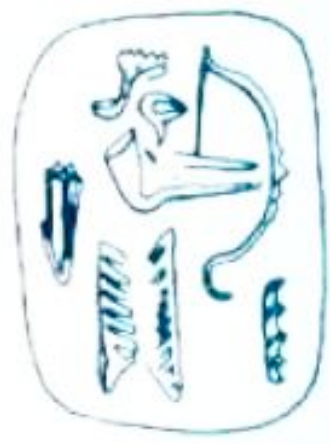

Figure 3. Stamp of Afrasiab Saghd (Xin, 2005).

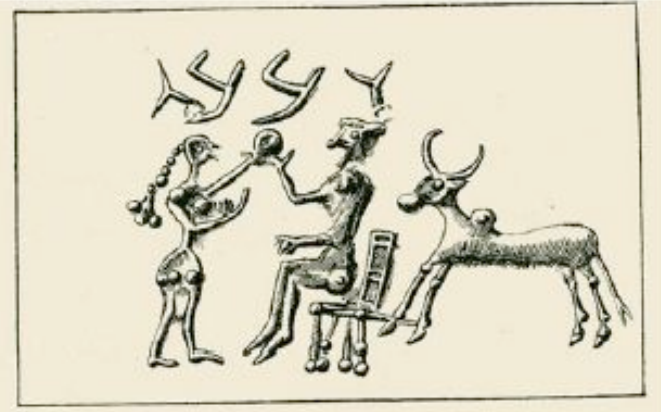

Design of cylindrical stamp of Jeihoun treasure (Xin, 2005).

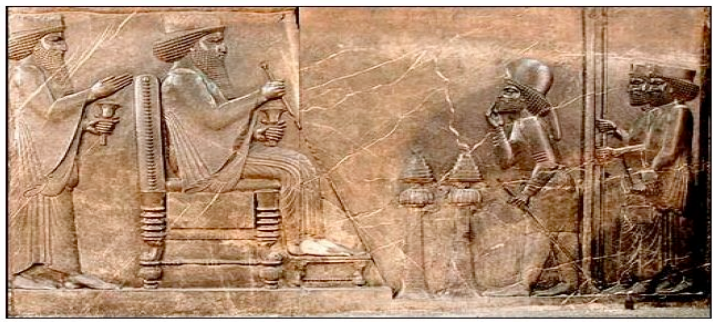


The Turkish Online Journal of Design, Art and Communication - TOJDAC October 2016 Volume 6 Issue 4

The scene of Baaraam Dariush in the stair of Apadana (Koch, 2004).

Figure 4. The comparison of challenging scene with the motifs of Apadana in Takht-e-Jamshid.

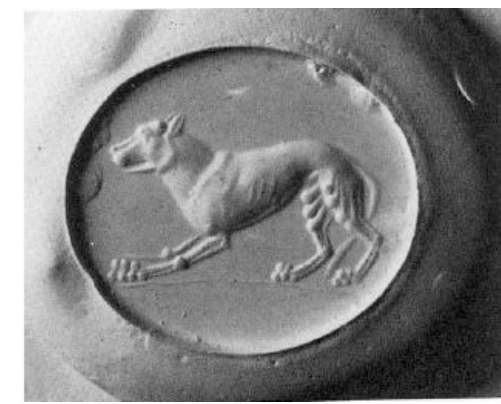

Figure 5. Design of a stamp from Ay Khanoum Temple in Bacteria (Xin, 2005).

\section{References}

Allen L, 2009. The history of Iranian emperor. translated by Abdi I, Tehran, amirkabir publication. 1.

Aruz J, Farkas A, Alekseev A, korolkova, E, 2000. The Golden Deer of Eurasia: Scythian and Sarmatian Treasure from the Russian Steppes, New York: The Metropolitan of Art.

Brosius M, 2010. Pax Persica and the Peoples of the Black sea Region: Extent and limits of Achaemenid Imperial Ideology. in Achaemenid Impact in the Black sea, Communication of Powers, Editted by Jens Nieling and Ellen Rehm, Aarahus University Press. Pp 29-40.

Bryan P, 1997. The history of the achaemenian emperor. volume 2, translated by semsar M, Tehran, Zaryab publication.

Carstens AM, 2006. Cultural contact and cultural change colonialism and Empire, In Rome and the Black sea Region: Domination, Romanisation, Resistance, Proceding of an International Conference university of Southern Denmark. Esbjerg, January 23-26, Editted by Bekker - Nielsen. Pp 119-131.

Dadvar A, Barazandeh Hosseini M, 2013. Religion and art in ancient Iran, Tehran, Ghostareh publication. 1.

Dusinberre ERM, 2002. King or God? Imperial Iconography and the "Tiarate Head" Coins of Achaemenid Anatolian Plateau Readings in the Archaeology of Ancient Turkey, Editted by Pavid. C. Hopkins. Pp 157-171.

Firouzmandi B, Bahadori A, 2011. The establishment of the Eastern states in achameneian kingdom. iranology studies, $1^{\text {st }}$ year. 1. Pp 23-42.

Frankfort HP, 1988. Central Asia and Eastern IRAN. The Cambridge Ancient History, Persia, Greece and the Western Mediterranean C. 525 to 479 B.C. Cambridge University Press. 4. Pp165-193.

Kertice J, Talice N, 2013. The forgotten emperor, the ancient Persian world, translated by: Mostofi F, Tehran, Ame Book. 1.

Koch H, 2004. Of Dariush language. translated by Rajabi P, Tehran, Karangh publication. 7.

Mirzaee AA, 2010. About the nature. coordination and framework of the achaemenian emperor, seasonal scientific research magazine of the Islamic and Iranian history, university of Alzahra, $20^{\text {th }}$ year, new period. 5, Frequent. 83. Pp 113-147.

Rajabi P, 2008. The lost millenniums. achaemenian by new concept. volume 2, Tehran, Toos publication. 3.

Rehm E, 2010. The Classification of object from the Black sea Region Made or Influenced by the Achaemenids. in Achaemenid Impact in the Black sea Communication of Powers, Editted by Jens Nieling and Ellen Rehm, Aarahus University Press. Pp 161-195. 
Tuplin C, 2007. Der Achamenid hof ( The Achaemenid Court). Heraugegeben Von Bruno Jacobs Und Rollinger.

Veisi M, 2009. The Iranian and Asia Minor communications in the achaemenian era. Alireza Hezhbari Nobari, a thesis for MA, archeology, university of teacher training center, Tehran, Iran.

Vogelsang WJ,1992. The Rise and Organistion of the Achaemenid Empire. Leiden.

Wiesehofer J, 2009. The Dynamics of Ancient Empires. State power from Assyria to By zantium, Editted by Ian Morris and Walter Schche: del, Oxford. Pp 66-99.

Wright A, 2012. Persianisation in the Art and Architecture of Achaemenid Provincial Palaces. 550-330 BC. in Ex Historia. Pp1-28

Xin W, 2005. Central Asia in the Context of the Achaemenid Persian Emoire (6 $6^{\text {th }}$ to $4^{\text {th }}$ Centuries B.C)". Doctor of Philosolhy, University of Pennsylvania, Holly Pittman (Supervisor of dissertation). 